\title{
Coping with religious-based segregation and discrimination: Efforts in an Indonesian context
}

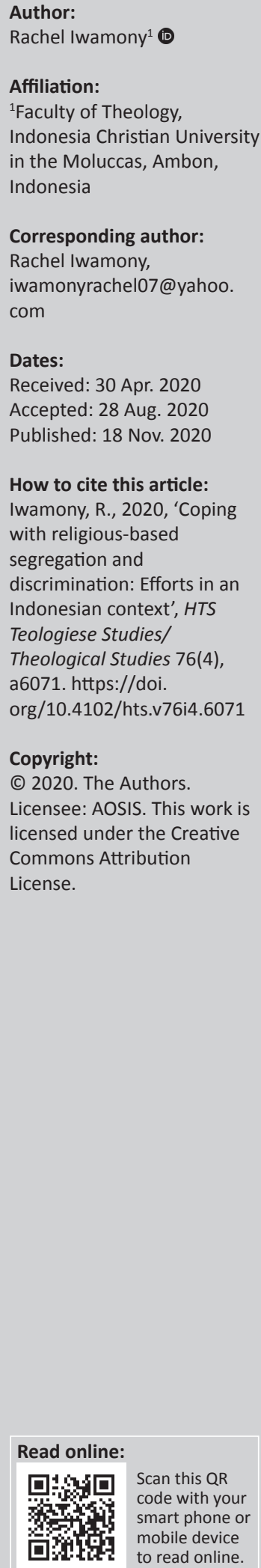

The aim of this article was to describe and analyse religious-based segregation and discrimination in the Moluccas and West Java, two places in Indonesia. Generally, people live peacefully side by side. However, in some places, social conflicts occur. By means of interview and focus group discussion, the researcher observed and concluded that the main cause of the conflicts was religious discrimination. In Moluccas, Christians and Muslims live separately. In coping with that problem, the local leaders keep trying to talk directly with one another and to engage in social acts together. Nevertheless, there are still some indigenous people experiencing religious discrimination. One of them is Sunda Wiwitan. Their access to acquire birth certificates has been hindered. Consequently, they have limited access to public services, including education and healthcare. However, their religious principles encourage them to be compassionate towards others and prohibit them from causing danger to others.

Contribution: Religious understanding and reconciliation have become important topics in the midst of religious conflict. This article contributes to promote religious reconciliation through some very simple and practical ways that reflect the core of religious teachings.

Keywords: Religion; Segregation; Discrimination; Violence; Non-violence; Indonesian religious life.

\section{Introduction ${ }^{1}$}

Indonesia is well known as an archipelago country. It has more than a 1000 islands, and it is divided into three significant areas: east, central and west. Indonesia has the biggest Moslem population in the world. Indonesia has many different cultures and religions, including Javanese, Sundanese, Batak, Borneo, Papuans, Bugis and Moluccans. Each of these cultures has influenced and shaped the character of its people. For example, Javanese are often quiet, whilst Batak and Moluccans are hot-tempered. ${ }^{2}$ Moreover, in Indonesia, six religions are officially recognised: Islam, Christianity (both Catholic and Protestant), Hinduism, Buddhism, Confucianism and many indigenous religions. The characteristics of people influence how they internalise and apply their faith.

This article discusses religious-based segregation in the Moluccan and religious discrimination experienced by Sunda Wiwitan, an indigenous religious people, in the West Java. These two communities are chosen because of their different characters. Although Moluccans are hottempered and slightly rough, Sundanese are more quiet and polite (Muhamad Aqros \& Val Madjid 2016:164). The Moluccans suffered social religious conflict in 1999-2004. Besides the destruction of institutions, such as hospitals, mosques, churches, schools, universities and public offices, many people lost their lives. During the conflict, Muslims and Christians did not share hospitals, schools, public offices and markets. John Pieris, an Indonesian politician from the Moluccas, has commented that (Pieris 2004):

The harsh nature of the Moluccas (though not everyone) often arises when they have a physical problem. This trait is often shown in case an opponent scoffs or arms them. It is very natural, and difficult to remove. This character is something that is considered to be common among the Moluccans. All people of the warring group clearly show the unrest in the Moluccas. However, harshness can be abandoned in case the opponent apologizes. A positive thing about hard-hearted individuals is that they are generally not vindictive. (p. 193)

1.The outline of this article has been delivered in the paralle group discussion of the Interdisciplinary International Conference on the Impact of Religion at Uppsala Universitet, Sweden, 24-26 April 2018.

2.See https://investor.id/archive/peneliti-konflik-1999-ubah-karakter-orang-maluku. 
By quoting Pieris' comment, this article intends to say that the characters of the Moluccans have a significant contribution to the social religious conflict that occurred and the current religion-based segregation.

Generally, the Sundanese run their daily lives based on their basic cultural principles, which is called silihasih, silihasah and silihasuh. Silihasih means to love each other; silihasah means mutual improvement (through education and knowledge); and silihasuh means to protect each other (Madjid \& Muhamad 2014:5). Especially the adherents of Sunda Wiwitan have their specific value systems that are called Cara Ciri Manusia and Cara Ciri Bangsa (Kunti 2017). One of the critical values of Cara Ciri Manusia is Tata Krama, which emphasises the order of behaviour and rules of conduct, such as politeness and courteousness (Wikipedia n.d.). As an implementation of tata karma, the core rules of conduct consist of just two elements: (1) do not do something detestable to others and (2) do not do something to harm yourself (Wikipedia n.d.). Therefore, the characteristics of the Moluccans and Sundanese have a significant impact on their social conditioning in the religionbased settlement segregation and discrimination.

\section{Method}

This research was conducted using a qualitative analysis. According to Hammarberg, Krikman and Lacey (2016):

Qualitative methods are used to answer questions about experience, meaning and perspective, most often from the standpoint of the participants ... Qualitative research techniques include 'small-group discussion' for investigating beliefs, attitudes and concepts of normative behaviour ... (p. 449)

The subject of this research is the people living and experiencing religion-based segregation and discrimination. Thus, to collect primary data, interviews and focus group discussions (FGD) with key informants were used. The researcher conducted interviews with six junior high school teachers and FGD with 20 local leaders (both Muslims and Christians).

\section{Conceptual framework}

According to the Oxford Dictionary, segregation is 'the act or policy of separating people of different races, religions or sexes and treating them differently' (ed. Wehmeier 2000:1158). It means that segregation refers to a situation where people in a society live separately or are treated differently because of certain categories such as race, religion and sex. By this meaning, one can say that segregation relates to exclusion because segregation expresses a willingness to exclude others. Segregation and exclusion are human attitudes that reject other people. Because of feelings such as fear and unsafeness, one tries to create a safe zone by excluding other people perceived as threats. Additionally, the people rejecting others are mainly in positions of power and authority and can make decisions and control others. On the contrary, rejected people have no rights to speak. In the Moluccas, Muslims and Christians rejected each other, yet they are the majority in the area.
Studies on segregation have been conducted by many scholars, including Nancy Denton and Douglas Massey. Conducting a study about racial and ethnic residential segregation in the United States, Denton and Massey (2012) classified the dimensions of spatial variation:

We began by conceptually classifying measures with respect to
five distinct dimensions of spatial variation: unevenness, exposure,
clustering, concentration and centralization. Unevenness is the
degree to which the percentage of minority group members within
specific neighbourhoods departs from the minority proportion in
the entire urban area. Exposure is the degree of potential contact
(or lack thereof) between minority and majority members within
particular neighbourhoods. Clustering is the extent to which
minority neighbourhoods adjoin one another in space.
Concentration is the relative amount of physical space occupied
by a minority group within a city; and centralization is the degree
to which minority members settle in and around the social or
geographic centre of a metropolitan area. (p. 40)

These five dimensions of spatial variation are found in residential segregation in the United States. However, they are found in all kinds of segregation, including the religionbased settlement segregation in the Moluccas. In 1999-2004, a time when the social religious conflict occurred, there was no interaction between Muslims and Christians. Each group had their own schools, hospitals and markets in their areas. Therefore, by using these five dimensions of spatial variation as a mirror to understand religion-based settlement segregation in the Moluccas, the writer wants to say that exposure and concentration were the dominant dimensions. However, a decade after the conflict, these dimensions have been transformed. Amongst these five dimensions, nowadays, exposure is the dominant dimension.

This condition pushes the minority to act as dependent people to the majority. This reflects an unhealthy society because there is inequality amongst people. Therefore, the writer agrees with Johnson (2014) who said that racial segregation prevents social learning:

Another claimed that racial segregation prevents social learning, the exposure of children to cultural practices other than their own, and ultimately greater racial interaction (Wells 1995). Segregation is also important because, by grouping people of a similar background, it ensures a greater number of them experience the same systemic inequalities. (p. 200)

According to the Oxford Dictionary, discrimination is defined as 'the practice of treating somebody or particular group in society less fairly than others' (ed. Wehmeier 2000:358). In addition, according to the Encyclopaedia Judaica (2007:679), 'discrimination is distinguishing between people on the basis of the group to which the person belongs rather than individual characteristic'.

Speaking about religious discrimination is speaking about religious rights. Vickers (2008) has an interesting and important notion about it. By quoting Edge, Vickers (2008) divided religious rights into four categories, namely:

$[T]$ he rights to a religious belief; the rights to a religious identity; the rights to be a member of a religious community; and the 
rights to act on such belief, identity or membership. This categorization usefully exposes the range of interests that a religious individual may have, and may help to define more clearly the range of behaviours or actions that may warrant protection. (p. 41)

From this categorisation, it is clear that individuals have rights to express their beliefs and to be recognised not only by each person in the community but also by a public institution, including a state. In this perspective, the writer agrees with Vickers' (2008) notion that:

The categorization of religious interests as including the right to belong to a community suggests that religious interests also contain a collective dimension, even though the recognition of religious interests presented above was cast in terms of individual rights, based on the principles of individual autonomy, dignity and equality. Indeed, the liberal basis of this line of reasoning is clear, and is based on a notion that human beings are individual and separate, with their own interests and moral rights. The right to freedom of religion is, on this view, a personal, individual interest. However, the concept of dignity, and the sense of identity which forms part of that, may demand some respect for community rights. This is because involvement in communities which share one's identity can be crucial to the development and enjoyment of a sense of identity and the experience of self-respect that goes with the valuing of that identity. (p. 42)

Vickers (2008) views an individual religious life in connection to a community. People cannot live their religious life outside a community, including a social community. In general, community helps an individual to live and express belief, and at the same time, the individual must develop it to contribute to the well-being and the interest of the entire community. Therefore, the community should be a safety zone for all people to live their religious life freely, something that requires freedom. As Moreau (2010) wrote:

This means that, in addition to certain freedoms of action, we are each entitled to a set of 'deliberative freedoms,' freedoms to deliberate about and decide how to live in a way that is insulated from pressures stemming from extraneous traits of ours. Many of us already have these deliberative freedoms. I shall argue that anti-discrimination law attempts to give them to all of us, because each of us has an independent entitlement to them. It attempts to give them to us by preventing our employers, service providers, landlords, and others from acting in ways that deny us opportunities because of these traits, so that when we deliberate about such things as where to work and where to live, we do not have to think about these traits as costs. I shall try to show that, by understanding anti-discrimination law in this way, we can make sense of its surface structure as correct. That is, we can understand why discrimination amounts to a personal wrong against the victim. It is a personal wrong because the discriminator has interfered with the victim's right to a certain set of deliberative freedoms. (p. 147)

According to Moreau (2010), the freedom of people to live and express their religion is deliberative. It means that religious people should contribute deliberately to the life of all human beings and the entire world. This is the essence of freedom, including religious freedom.
This conceptual framework shows that segregation and discrimination have a connected notion, that is, to treat a person differently based on a certain criterion. The differentiation is based on the basic notion that somebody or a particular group is less worthy because they are different. Therefore, segregation and discrimination are theological problems that must be discussed because they create exclusion and injustice in society. They contravene the essence of religion that teaches embracing and loving each other rather than exclusion and enmity.

\section{Religion-based settlement segregation in the Moluccas}

The segregation of religion-based settlement is prevalent in the Moluccas. Muslims and Christians live in separate places. Hence by mentioning the place where people live, one can recognise their religion. Religion-based settlement segregation in the Moluccas is believed to be the impact of the socioreligious conflict that occurred in 1999-2004. Although this can be true, religion-based segregation has been present since the Dutch colonial period. In the Dutch colonial period, local people in the Moluccas, especially in the Ambon city, were divided based on their religions. Ambon Island was and still is divided into two areas: Leihitu and Leitimur. All the villagers in Leihitu are Muslims, whilst Christians live exclusively in Leitimur (Ismail 2017:96). In the colonial period also, they were treated differently. Christians acquired more access to education compared to their local Muslim brothers and sisters.

In the past, to confess a religion was not an individual choice, but a communal decision. Consequently, there was only one religion in a village. Ironically, when a village had more than one religion, it had to be divided based on the religion of its citizens. For example, Siri Sori at Saparua Island was one village which had to be divided into Muslim Siri Sori and the Christian Siri Sori villages. This shows that segregation of religion-based settlements in the Moluccas existed for years before the socio-religious conflict started. Precisely, the segregation of religion-based settlement is not a new phenomenon in the Moluccas that just shaped during and after the socio-religious conflict. It was a colonial approach to divide local people and gain dominance. Some of the Moluccan local cultures reflect this point of view. Amongst them, Pela $^{3}$ is one. In the local perspective, an outsider is a threat to insiders. Insiders feel insecure when they are out of their own community; they have the same feeling when outsiders enter their community.

Before the social conflict, the dominant religion had slowly been reduced. The newcomers at the Ambon city live amongst the local people, including the believers of different religion. Therefore, the monotheistic religion of an area changed into majority and minority. Mostly, the local people with their religion were the majority, whilst the newcomers were minority. This transformation was a social development that had a great impact on religious life. People celebrated

3.Pela is a Moluccan cultural system that connects people from two or three villages in brotherhood-sisterhood relationship. 
religious event freely. However, they now had to consider other religious people living amongst them and might not want to see and hear other religious activities. This situation created unspoken tension amongst religious people.

Regarding the tendency of the majority to control over the minority in the Moluccas, Pieris (2004) stated that:

The author sees it during the coercion of the will of the majority to the minority. There is often religious discrimination or unfair treatment of certain religious (religious) groups within the field of politics and bureaucracy in Indonesia. This has been experienced in the Moluccas for decades. Bureaucratic politicization often occurs in the Moluccas Provincial Government, and the impact occurs on the Local Government of Ambon City, then spread to the regional government of Central Maluku. (p. 41)

For the tensions, Pieris (2004) continued to state:

In North Maluku and Halmahera districts, there is almost no place for Christian religious minorities. When the unrest broke out, Christian minorities became victims, killed and expelled from Ternate and Tidore. On the contrary, the same thing is done by the Christian majority in the region. There is a politics of revenge based on religion. (p. 41)

After conducting a research in the Moluccas in 2017, Ismail (2017) concluded that:

The Moluccans' settlement pattern after the social conflict in 1999 is religiously based and not in the ethnic category. Segregation of religious-based [sic] settlement in Ambon city strengthens religious solidarity than cultural solidarity which penetrates practical political issues. Therefore, in the local political context, religion is a determining factor for someone to vote. (Ismail 2017:131-132) Moreover, he continued to conclude that 'In the context life in the Moluccas and especially in the Ambon city, religion is determining factor in all aspects'. (p. 132)

The conclusion of Ismail (2017) confirms a point of view of an interviewee, who said:

In my opinion, the factors that cause people to live apart are the conflicts of 1999. Sadly, after the conflict, religion still becomes a political issue in many political events which contributes to religious conflict. ${ }^{4}$

Research in the Moluccas, specifically in the Ambon city, showed the negative impacts of religion-based settlement segregation. Firstly, it strengthens religious solidarity and decreases human solidarity. Secondly, it perpetuates the trauma caused by the social conflict. Thirdly, it strengthens political identity (Ismail 2017:133). Without [AQ9] community cohesion, the trauma healing process cannot be successful.

\section{Efforts to cope with the segregation of religion-based settlement}

The negative impacts of segregation of religion-based settlement, as stated above, affect all people in the Moluccas.

4.An interview with Cecep on 21 February 2018 at Junior High School at Liang, Salahutu, Ambon.
Various measures to overcome these negative impacts include the following:

1. Live in Program

2. Exchange guests at religious events

3. Intensive communication between local leaders

4. Neighbourhood social activities

5. Pela schools and Pela university

The Live in Program was launched by the Maluku Interfaith Institute, an institution that facilitates the process of resolving socio-religious conflicts in the Moluccas. Throughout this programme, several Christian religious teachers stayed with Muslim families. Similarly, some Islamic religious teachers stayed with Christian families. Through this programme, Islamic and Christian religious teachers understand the lives of Christian and Muslim families. Consequently, suspicion and fear between Muslims and Christians were lessened. Sharing her experience as a participant of this programme, an interviewee said: 'staying with a Muslim family helped me to transform my negative point of view about Muslims'. ${ }^{5}$ After participating in the programme, the Islamic religious teacher from SMP Negeri 4 Salahutu, a public Junior High School, and the Christian religion teacher from SMP Negeri 9 Lateri, a public Junior High School, agreed to establish the two institutions as Pela schools. As religious teachers, they both admitted that segregation of religion-based settlement deprives students the opportunity to experience a pluralistic life. Therefore, fear and suspicion amongst them are quite strong. Their relationship as a Pela school has been going on for approximately 5 years, with significant influence on the acceptance of each other (Iwamony, Gaspersz \& Souisa 2019:86-89).

The Guest Exchange programme is a strategy implemented when a religious activity involving guests from outside the Moluccan Province takes place in the Ambon city. The guests are accommodated in houses around the city. When Islamic religious activities take place, Islamic guests stay in the homes of Christians. Similarly, during Christian religious activities, Muslims host Christians. This offers an excellent opportunity to share burdens. Although they live segregated, they still share burdens, which is the core of loving each other. Moreover, allowing a stranger to stay in a home is hospitality.

The impact is not only for the residents of the Ambon city but also for the guests from outside the province. When the National Musabaqah Tilawah Al-Quran (MTQ) competition took place in the Ambon city in 2014, participants from the Banten Province, West Java, stayed in Kudamati, a Christian area in the Ambon city. The negative impression of the Muslim-Christian relationship in the Moluccas was erased after enjoying hospitality.

Higher education institutions are also involved in the efforts. By implementing Moluccan local culture, the Universitas Kristen Indonesia Maluku (UKIM) and the Institut Agama 5.An interview with Mrs An, a religious teacher at SMP Negeri 9 Lateri-Ambon, on 26 February 2018. 
Islam Negeri (IAIN) formed a special relationship as a Pela university. The formation of a prestigious university facilitated inter-religious life. These two faith-based universities inspire cross-religious living, ideas and practices. There was a sharing of human resources between these universities, that is, UKIM utilises teaching staff from IAIN and vice versa. When UKIM had the opportunity to bring guest lecturers from abroad, the guest lecturers were asked to teach at IAIN. As institutions of higher education, IAIN and UKIM should encourage each other in the development of these two universities. In the framework of Pela, unfair competition between these two educational institutions is not justified because the progress of IAIN is also the progress of the UKIM.

Moreover, communication between local leaders has been created since the socio-religious conflict in the Moluccas in 1999-2004. Local leaders, who were the heads of the neighbourhood, communicated to ascertain issues that came up. This approach helped to stop the conflict between Muslims and Christians, which was triggered by provocation. In the FGD, all local leaders agreed that 'much violence occurs because people reacted easily to provocation. Through communication among leaders of local communities, the truth could be confirmed, which prevented conflict and violence' ${ }^{6}$

After the socio-religious conflict, communication between the Muslim and Christian leaders at the grassroots level is still maintained. They visit each other and conduct joint activities. These practical things help Muslims and Christians to overcome the negative impacts of the segregation. According to the local leaders: '[i]nformal gatherings such as having a cup of coffee together is a simple way of having face to face meetings and talk about problems at the grassroots level'. ${ }^{7}$ This has a significant impact on relations between Muslims and Christians living in a segregation pattern. To support those practices, Vendeley (2009) stated that:

The idea expressed the agreement that an individual's security is related to the security of others. Religious leaders are called along with their faithful and all humanity to work together to promote common security. (p. 689)

Communication between the local leaders is an attempt at reconciliation on a local level. On a broader level, such as the community, there is a practice of mutual greeting during a religious feast. According to some interviewees, 'although Muslims and Christians live apart, they still appreciate each other. This is seen during Christmas and Idul Fitri and Ramadhan, where they visit and greet each other' ${ }^{8}$ Travelling home during Idul Fitri and Christmas has become one of the habits of Moluccan Muslims and Christians (Iwamony \& Relmasira 2017:18). However, such practice was somewhat

6.Focus group discussion with local leaders at Santo Jacobus Church, Ahuru, on 10 January 2017.

7.Focus group discussion with local leaders at Santo Jacobus Church, Ahuru, on 10 January 2017.

8. Interview with HM on 24 February 2018 at his office. Interview with RS on 01 March 2018. disrupted in recent years when Muslims were forbidden from greeting Christians.

All of the above efforts reflect the willingness of the community to cope with the religion-based settlement segregation. Therefore, all people in the community work together to keep contact, to create space to meet each other and to share their burdens. All these point to a basic value of a pluralistic society, that is, trust building.

\section{Religious discrimination experienced by the believers of Sunda Wiwitan}

Sunda Wiwitan is an indigenous religion in the West Java which is also discriminated against. The adherents of Sunda Wiwitan believe in their ancestors who introduced them to and taught them about the Supreme Being called Hyang Kersa.

The community faces many kinds of religious discrimination, such as receiving the Indonesian identification (ID) card and birth certificate as well as learning about other religions as a subject in school. In the Indonesian ID card application, there is a column for religion. When the Sundanese people apply, the officers or the state do not want to write Sunda Wiwitan in the column of religion. According to the officers, the applicants have to choose one of the officially recognised religions; otherwise, they cannot receive official ID cards. Furthermore, when they want to get married, they have to fulfil all required administration documents, where they have to choose a recognised religion; otherwise, they cannot be served. Moreover, children of the Sunda Wiwitan's adherents often experience religious humiliation from their schoolmates. In their schools, they are forced to study other religious subjects (Kunti 2017). According to Dewi Kunti, an adherent of Sunda Wiwitan who is also an activist, the local government also does not recognise Sunda Wiwitan as a religion. Their religious rituals are perceived as mere cultural ceremonies (Kunti 2017).

Principally, it should be that religion, culture and ideology should not be a criterion for a state to serve its citizens. A citizen is served because she or he has the right to be served. Religion should not be an identification element in the Indonesian ID card. Having no ID card and the birth certificate has a big impact on their rights as Indonesian citizen. They may not have access to public health services and other public services, which amounts to injustice in the society. It is injustice because other religious people such as Muslims, Christians, Hindus, Buddhists and Kong $\mathrm{Hu} \mathrm{Cu}$ have full access to all public services.

The issue of the rights to obtain religious status in the ID column is still being debated. By quoting Arbi Mulya Sirait and friends, Sabandiah and Wijaya (2018) wrote that the system of filling the religion column on the ID card as applied today could be considered as 'progress' for the adherents of the Djawa Sunda teachings. In the religion 
column on their ID card, it is written with a dash (-). This can be considered as progress because they are no longer required to include the name of a particular official religion in their ID card (Sabandiah \& Wijaya 2018:345). Indicating a dash (-) is preferable to specifying a particular official religion. However, this idea still supports religious discrimination because the believers of indigenous religions are considered as having no religion. A dash is an indication of rejecting religion of indigenous people. It is an unfair act of injustice committed by the state. The believers of indigenous religions are served differently. Theologically, this means that their dignity as grace from God has been humiliated. Therefore, they should be encouraged to continue fighting for their rights.

\section{Coping with the religious discrimination}

Religious discrimination faced by the adherents of Sunda Wiwitan expresses some fundamental theological problems. The believers of Sunda Wiwitan lost the rights to a religious identity and the rights to act on such belief, identity or membership (Vickers 2008:4). They lost their religious identity when the local officers do not fill out the column of religion in the Indonesian ID application form as well as in the birth certificate form. The same principle is also applied to how students are treated at school, where they have to join other religion classes. In addition, the community lost its rights to act on such a belief when their religious rituals are perceived as mere cultural ceremonies. Those all are expressions of treating people's existence as invisible. In the theological perspective, it is an expression of rejecting human dignity.

To prevent all kinds of discrimination, the community should be aware that they are experiencing it. Awareness creates sensitivity to discover and a small possibility to reclaim their rights. Awareness is a fundamental spirit to keep work for justice. The believers of Sunda Wiwitan are aware that they are discriminated against. Therefore, they try to combat the religious discrimination through the following efforts:

- Registering their community at Indonesian Ministry of Education and Culture.

- Maintaining their belief system through their culture and art.

- Documenting the practice of constitutional violations committed by the state against the Sunda Wiwitan community.

In facing religious discrimination, the adherents of Sunda Wiwitan try to find their own way of fighting for their rights. According to Dewi Kunti, 'we fight for the rights of Sunda Wiwitan's adherents without using violence' (Kunti, SAAT Malang 2017). Therefore, to keep their faith, which are also their cultural systems, alive and be recognised by local officials, they try formally to have their own community by registering at the Indonesian Ministry of Education and
Culture, although the religion column still is not filled out (Sunda Wiwitan 2015). Precisely, there is no change for seeing Sunda Wiwitan as a religion. However, it is understandable because they did not register at the Indonesia Ministry of Religion. By registering at the Ministry of Education and Culture, they acknowledge them as a cultural community. This contradicts what they are fighting for, which is seeking the recognition of their religion by the state. Thus, in order to attain their goal, they have to register at the Indonesian Ministry of Religion.

To keep their beliefs alive, they strive to maintain their traditions by producing Sundanese wood carvings, batik, dances, songs and architecture of building with their symbols. They speak about their existence through their customs. However, this does not stop the religious discrimination they face. This is because these activities are considered to be mere cultural expressions. They need to speak to the world about their problem through documentation.

Documenting all practices of constitutional violations committed by the state helps to fight against discrimination without violence. Documentation is a process of collecting and filing proof or evidence of an act or a fact. In this case, the act or the fact is all kinds of religious discriminations committed by the state. Dewi Kunti has many documents as proof. Precisely, documentation proves that they have data, and thus, they work in a legal way. Their conversation about religious discrimination is not meant to slander the state. It is real in their daily lives. This way justifies the point of view of Sunda Wiwitan community that they will fight to reclaim their rights back without harming others. The way the community fights to regain their rights forms a critical perspective to rethink the notion that religious discrimination leads to conflict or war (Basedau \& Schaefer-Kehnert 2019:30-47).

Fighting for their rights using legal means is another implementation of their belief value that has a significant impact on their daily conduct and behaviour. Generally, Sundanese are very polite people. They shun activities such as demonstrations. Because the state commit religious discriminations, their efforts hardly work. However, they cannot abandon such efforts because they are related to their cultural perspective and belief value.

To prevent all kinds of discrimination, people must speak loudly, especially when the state or local officers commit it. Principally, religious discrimination is not an accident or coincidence, but a condition that is created and planned, although it is against Article 29 of the Constitution of Indonesia as drafted in 1945 (Fadli 2017:602). People are discriminated by an established system. They live on the periphery of the social and cultural world, and therefore, they are oppressed and marginalised and their humanity is demeaned. Discrimination is destructive, and it is not by chance that all religions speak about justice to the oppressed and marginalised. At this point, the religious discrimination faced by the adherents of Sunda Wiwitan is a problem of all human beings. All religious people have the responsibility to 
work together to fight for justice to Sunda Wiwitan's adherents to get their rights as Indonesian citizen. Especially for Christians, it is the implementation of their faith to work for justice and equality, as Volf (2013) wrote:

[...] Christianity isn't just one religious perspective among others; rather, the Christian faith (in some of its articulations, which originated in the West) is the basis of a particular proposal for how to organize public life in a way that treats people of all faiths and of no faith at all with equal respect. (p. 820)

The adherents of Sunda Wiwitan have to raise their voices loudly to help Indonesia to transform how its apparatus serves the citizen. Sometimes, decision-makers at the national level do not know about the policy at the grassroots level. Thus, documentation as a way to work for coping with the religious discrimination should be appreciated. In this context, the adherents of Sunda Wiwitan who are discriminated against do not see the state as their enemy. They also do not take opposite position to state because opposition approach tends to create conflict.

\section{Conclusion}

Religion-based segregation and discrimination in the Moluccas and the West Java and the efforts to cope with them reflect how religion plays a significant role in social life as well as in public services in Indonesia. Ironically, in the name of religion, segregation settlement and discrimination occurred in Indonesia. Besides, the character of a community also shapes how religious people live their faiths. The last perspective can be noted in these two communities. When they are in a majority, the Moluccan Christians tend to take control over the Muslims, and vice versa. Therefore, they create their own settlement segregation. On the contrary, the adherents of Sunda Wiwitan are discriminated against by the state. However, they did not reclaim their rights using violence. Precisely, the Moluccans and Sundanese have different ways to cope with their situations.

In the Moluccas, all social and religious elements work together to cope with their segregation situation by performing some programmes that enable them to meet, interact with and support each other by sharing burdens, joys and their lives. In other words, in the Moluccans' settlement segregation, it was found that sharing life is a fundamental principle of a belief. Segregation settlement does not prevent the Moluccans to share their lives. The adherents of Sunda Wiwitan try to speak up about their religious discrimination to reclaim their rights without harming others, even the state.

\section{Acknowledgements}

The author wants to express her gratitude to the following people who supported her in completing this work: the teachers at SMP Negeri 9 Lateri and SMP Negeri 4 Salahutu, especially Mr Cecep and Mrs An, who helped by sharing their experiences about the Live in Program; local leaders at Ahuru, who helped by attending focus group discussions and by sharing their experiences about working on the reconciliation process between Christians and Muslims at the grassroots level, during and after the socio-religious conflict in the Moluccas; Mrs Dewi Kunti, an activist and an adherent of Sunda Wiwitan, who shared her efforts to reclaim their religious rights in an academic class at SAAT Malang, Indonesia.

\section{Competing interests}

The author declares that she has no financial or personal relationships that may have inappropriately influenced her in writing this research article.

\section{Author's contribution}

R.I. is the sole author of this research article.

\section{Ethical considerations}

This article followed all ethical standards for research without direct contact with human or animal subjects.

\section{Funding information}

This research received no specific grant from any funding agency in the public, commercial or not-for-profit sectors.

\section{Data availability}

Data sharing is not applicable to this article as no new data were created or analysed in this study.

\section{Disclaimer}

The views and opinions expressed in this article are those of the author and do not necessarily reflect the official policy or position of any affiliated agency of the author.

\section{References}

Aqros, M. \& Madjid, V., 2016, Peran Nilai Budaya Sunda dalam Pola Asuh Orangtua bagi Pembentukan Karakter Sosial Anak (studi deskriptif di Desa Suntajaya Kec. Lebang Kab. Bandung Barat), Universitas Pendidikan Indonesia, Skripsi, Bandung.

Basedau, M. \& Schaefer-Kehnert, J., 2019, 'Religious discrimination and religious armed conflict in sub-Saharan Africa: An obvious relationship?', Religion, State and Society 47(1), 30-47. https://doi.org/10.1080/09637494.2018.1531617

Encyclopaedia Judaica, 2007, Discrimination, in Fred Skolnik (ed.), 2nd edn., Keter Publishing House Ltd., Farmington Hills.

Fadli, M., 2017, 'Constitutional recognition and legal protection for local religion in Indonesia: A discourse on local religion of the Tengger and Baduy people', Pertanika Journal of Social Sciences \& Humanities 25(2), 601-614.

Hammarberg, K., Kirkman, M. \& De Lacey, S., 2016, 'Qualitative research methods: When to use them and how to judge them', Human Reproduction Journal 31(3), 499. https://doi.org/10.1093/humrep/dev334

Ismail, A., 2017, Prahara yang Terselubung, Trussmedia Grafika Agung, Yogyakarta.

Iwamony, R., Gaspersz, S. \& Souisa, N., 2019, 'To embrace and be embraced: School pela in post-conflict Ambon', Studies in Interreligious Dialogue 29(1), 83-101. https://doi.org/10.2143/SID.29.1.3286456

Iwamony, R. \& Relmasira, T.A., 2017, 'Rekonsiliasi Sebagai Proses Bersama Menyembuhkan Luka Sejarah Islam Kristen di Kota Ambon', Religió: Jurnal Studi Agama-Agama 7(1), 1-27. https://doi.org/10.15642/religio.v7i1.706

Johnson, Jr. O., 2014, 'Still separate, still unequal: The relation of segregation in neighborhoods and schools to education inequality', The Journal of Negro Education 83(3), 200. https://doi.org/10.7709/jnegroeducation.83.3.0199

Madjid, M.A.S.R.V. \& Muhamad, I.A.A., 2014, Peran Nilai Budaya Sunda dalam Pola Asuh Orang tua bagi Pembentukan Karakter Sosial Anak, Universitas Pendidikan Indonesia, Skripsi, Bandung. 
Massey, D.S., 2012, 'Reflection on the dimensions of segregation', Journal Social Forces 91(1), 40. https://doi.org/Doi:10.1093/sf/sos118

Moreau, S., 2010, 'What is discrimination?', Philosophy Public Affairs 38(2), 143-179. https://doi.org/10.1111/j.1088-4963.2010.01181.x

Pieris, J., 2004, Tragedi Maluku: Sebuah Krisis Peradaban: Analisis Kritis Aspek: Politik, Sosial-Budaya dan Keamanan, Yayasan Obor, Jakarta.

Sabandiah, R.N. \& Wijaya, E., 2018, 'Diskriminasi terhadap Agama Tradisional Masyarakat Hukum Adat Cigugur', Jurnal Penelitian Hukum De Jure 18(3), 335-352. https://doi.org/10.30641/dejure.2018.v18.335-352

Sunda Wiwitan, 2015, Sunda Wiwitan, Diskriminasi dan Penguatan Tradisi, viewed 13 April 2020, from https://crcs.ugm.ac.id/tag/sunda-wiwitan/.
Vendeley, W., 2009, 'Kekuatan Agama-Agama Untuk Perdamaian', in E. Peldi Taher (ed.), Merayakan Kebebasan Beragama: Bunga Rampai 70 Tahun Djohan Effendi, p. 698, Kompas \& ICRP, Jakarta.

Vickers, L., 2008, Religious freedom, religious discrimination and the workplace, Hart Publishing, Portland, OR.

Volf, M. 2013, 'Faith, pluralism, and public engagement', Political Theology Journa 14(6), 813-834. https://doi.org/10.1179/1462317X13Z.00000000053

Wehmeier, S. (ed.), 2000, Oxford advanced learner's Dictionary, 6th edn., Oxford University Press, New York, NY

Wikipedia, n.d., Sunda Wiwitan, viewed 13 April 2020, from https://en.wikipedia.org/ wiki/Sunda_Wiwitan. 